\title{
Application and Exploration of WPBL Teaching Model in Surgery Teaching
}

\author{
Qianli Tang1, Shu Wang1, Dandan Xie', Xiaoqiang Mo', Xusen Huang², Haige Huang², Jiehui Li³, \\ Hongmeng Zeng 3
}

\footnotetext{
${ }^{1}$ Youjiang Medical University for Nationalities/Clinical Medical Research Center of Liver Disease in Guangxi, Baise, China ${ }^{2}$ Department of General Surgery, Affiliated Hospital of Youjiang Medical University for Nationalities, Baise, China ${ }^{3}$ Fifth Department of Surgery, The First Affiliated Hospital of Guangxi University of Chinese Medicine, Nanning, China Email: htmgx@163.com
}

How to cite this paper: Tang, Q. L., Wang, S., Xie, D. D., Mo, X. Q., Huang, X. S., Huang, H. G., Li, J. H., \& Zeng, H. M. (2017). Application and Exploration of WPBL Teaching Model in Surgery Teaching. Creative Education, 8, 650-656. https://doi.org/10.4236/ce.2017.84049

Received: January 16, 2017

Accepted: April 27, 2017

Published: April 30, 2017

Copyright $\odot 2017$ by authors and Scientific Research Publishing Inc. This work is licensed under the Creative Commons Attribution International License (CC BY 4.0).

http://creativecommons.org/licenses/by/4.0/

\begin{abstract}
Objective: To investigate the application of WPBL (Web Problem-Based Learning) teaching model in surgical teaching so as to better explore and research surgical teaching model. Methods: Questionnaire survey was given to the objects selected from students and teachers of Youjiang Medical University for Nationalities through random table number. Results: Most of the teachers knew about WPBL teaching model and agreed with the introduction of WPBL. As for the students' satisfaction degree for teaching methods, almost half of the students believed that the teachers could apply flexible and various teaching methods in the classroom teaching, $18 \%$ of the students thought that only a small number of teachers met the requirement, but there were still $2 \%$ of the students who held that teachers didn't meet above-mentioned requirement. Conclusion: Teachers have a certain understanding about WPBL teaching model, but the understanding is not deep enough, so the standardized teaching training for teachers is very necessary. At the same time, the students' high satisfaction degree for teaching and teachers approval indicated that WPBL teaching mode can be recognized by the teachers and students consistently.
\end{abstract}

\section{Keywords}

WPBL, Surgery, Teaching Model, Teaching Mode Reform, Questionnaire Survey

\section{Introduction}

WPBL (Web Problem-Based Learning) is based on network teaching environment and teaching resources. Centering on the problem, teachers and students have a discussion together to achieve a deep understanding of the teaching con- 
tent and to improve the students' comprehensive quality such as: Ability of analyzing and solving problems and the like through practice (Zhao, 2013). It makes full use of network resources in network environment. Centering on the problem and the specific medical record, by discussion of the active approach to learning, it can facilitate communication between teachers and students and improve students' self-study enthusiasm and problem solving ability (Neville, 2009). The traditional teaching mode is teacher-centered, in which students can only remember and verify theory knowledge passively and repeatedly. This kind of teaching mode leads to students' lack of independent thinking and problem solving skills, and it can not meet the requirements of today's society for applied talents (Han, Hu, Song et al., 2012). The disadvantage of traditional teaching is particularly acute in surgery which centers on practical ability. At the same time, because of the particularity of clinical medicine, the knowledge from medical textbook often lags behind the knowledge from clinic for 5 - 10 years, and the knowledge learned from textbook is often outdated (Wang, 2009). Hence, surgical teaching can not be entirely based on textbooks, especially in post-surgery education. After a previous theoretical knowledge learning, the teaching materials should be combined with clinic, mainly clinic, the theory should be combined with practice, mainly practice (Li, Zhang, Huang et al., 2016). Therefore, how to combine clinical practice with theoretical knowledge to explore a better teaching method becomes a top priority. This project attempts to apply the WPBL teaching mode to the surgery theory and experiment teaching and explore the new teaching mode, aiming to provide new ideas for the reform of surgical teaching.

\section{Advantages of WPBL Teaching Model}

\subsection{Full Usage of Network Resources}

WPBL is based on PBL teaching method. It utilizes PBL's advantages of rich network resources and has no limitation of time and space, so as to greatly enlarge the number of learners and resource, and improve learning flexibility of PBL. The network can provide students with graphic, audio-visual, colorful interactive human-machine interface and can express the abstract problem in a more intuitive way. WPBL teaching method can make full use of the advantages of abundant network resources, large amount of information, vivid content, convenient communication to promote the students to build up a habit of learning from the network resources, so as to improve students' ability of analyzing and solving problem (Wei, Lu, Long et al., 2010). At the same time, the discussion of the real clinical cases is conducive to the cultivation of the humanities spirit (Liu, 2017).

\subsection{Network Environment for Teachers and Students to Cooperate and Communicate Conveniently}

Teaching platform can provide online graphic and video communication tools, thus facilitating the instant communication between teachers and students, whi- 
ch directly shorten the distance between teachers and students. Therefore, the problem can be solved in the shortest time, and the learning efficiency is greatly improved (Li, Wang, \& Xiao, 2011; Huang, Ma, Cui et al., 2014).

\subsection{Improvement of Students' Initiative in Self-Learning}

In traditional teaching model, teachers always inculcate lots of basic theoretical knowledge in students, and fail to organically combine basic knowledge with clinical knowledge, so students often feel bored and are easy to lose interest in the process of learning, which leads to poor learning effect in the entire course. In WPBL teaching model, teachers carefully compile some real cases and problems, and organically combine the theory with clinic. Students analyze real clinical cases and solve problems happened in practical work. WPBL can stimulate students' interest of learning easily (Long, Wei, Lu et al., 2013; Yang, Li, \& Lin, 2014).

\subsection{Improvement of Students' Ability of Problem Solving}

The basic form of WPBL teaching is that students work in cooperation groups to solve complex and practical problems. It has unique advantages in training medical students' innovation ability, solving problems ability and the ability of independent learning (Deng, Peng, \& Deng, 2014). It also can better cultivate students' ability of discovering, thinking and solving problems and can strengthen teamwork ability, interpersonal skills and students' language ability. In cultivating creative, pioneering and practical medical talents, WPBL teaching methods have the advantages that traditional teaching model cannot match ( $\mathrm{Li}$, Wang, Xiao et al., 2011; Huang, Ma, Cui et al., 2014; Long, Lu, Wei et al., 2013).

\section{Research}

\subsection{Research Concerning Teachers}

The subjects of the questionnaires include 268 teachers who teach in the university and clinical department. Among which 87 teachers teach foundation course, 181 teachers teach clinical medicine (surgery: 63, internal medicine: 60, obstetrics and gynecology: 9, pediatrics: 13, other majors: 36); Male teachers: 102, female: 166; 19 teachers of doctor's degree, 106 of master's degree, 143 of bachelor's degree; 9 professors, 45 associate professors, 98 lecturers, 116 teaching assistants.

Survey data in Figure 1 show that surgery teachers and other major teachers have almost consistent understanding of WPBL teaching method $(P>0.05)$. Most teachers knew the WPBL teaching methods, accounting for 93\% (surgery teachers $93.65 \%, 59 / 63)$, Only $7 \%$ of the teachers were unclear about WPBL (surgery teachers $4.76 \%, 3 / 63$ ), $49 \%$ learned about it through domestic literature(surgery teachers $46 \%, 29 / 63$ ), while $29 \%$ learned about it through the foreign literature(surgery teachers $38 \%, 24 / 63$ ), $15 \%$ by other means(surgery teach- 
ers $11 \%, 7 / 63)$.

Data in Figure 2 show that most of the teachers agreed with the introduction of WPBL, accounting for $87 \%$, among which $31 \%$ totally agreed and $56 \%$ partly agreed. $9 \%$ of the teachers held a neutral attitude and only $4 \%$ of the teachers didn't agree to introduce it.

\subsection{Research Concerning Students}

Questionnaires were given to 371 students including 180 junior students majored in clinical medicine of five-year system, 89 postgraduates (professional) and 102 resident doctors receiving standardized training $(5+3$ standardized trainees).

Data in Table 1 show that the majority of students were satisfied with teachers' teaching methods, but only $8 \%$ of the students believed that all the teachers could apply flexible and various teaching methods in the classroom teaching. $47 \%$ thought that only $75 \%$ of the teachers could meet the requirement mentioned above, $25 \%$ thought that half the teachers met the requirements. $18 \%$ of the students thought that only a small number of teachers met the requirements, but there were still $2 \%$ of the students who held that teachers didn't meet abovementioned requirement.

\section{The Sources for teachers learning of WPBL teaching}

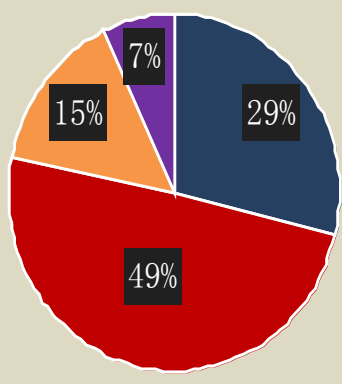

- Foreign Literature

- Domestic

literature

$\square$ ther methods

- Do not know

Figure 1. Statistics of the sources for teachers learning of WPBL teaching.

Teachers' attitudes towards the introduction of WPBL

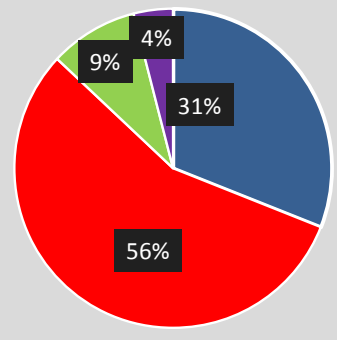

- Totally agree

- Partly agree

$\square$ It does not matter

- Disagree

Figure 2. Statistics of teachers' attitudes to the introduction of WPBL. 
Table 1. Description of students' satisfaction degree for teachers' teaching methods.

\begin{tabular}{cccc}
\hline Item & Option & Number & Rate \\
\hline & All & 30 & $8 \%$ \\
Students' satisfaction & Most & 175 & $47 \%$ \\
degree for teachers' & Half & 93 & $25 \%$ \\
teaching methods & Small part & 67 & $18 \%$ \\
& None & 6 & $2 \%$ \\
\hline
\end{tabular}

\section{Analysis and Conclusion}

We got the following results from the survey: $93 \%$ of the teachers knew about WPBL teaching model. Among them, 49\% learned about it through domestic literature, while $29 \%$ learned about it through the foreign literature, $15 \%$ by other means. Only $7 \%$ of the teachers were unclear about WPBL teaching model. In addition, about $87 \%$ of the teachers agreed with the introduction of WPBL, among which $31 \%$ fully agreed to introduce it, $56 \%$ agreed partly. $9 \%$ of the teachers held a neutral attitude and only $4 \%$ of the teachers didn't agree to introduce it. As for the students' satisfaction degree for teaching methods, the majority of students were satisfied with teachers' teaching methods, but only $8 \%$ of the students believed that all the teachers could apply flexible and various teaching methods in the classroom teaching. $47 \%$ thought that only $75 \%$ of the teachers could meet the requirement mentioned above, $25 \%$ thought that half the teachers met the requirements. $18 \%$ of the students thought that only a small number of teachers met the requirements, but there were still $2 \%$ of the students who held that teachers didn't meet above-mentioned requirement.

The study of clinical medicine must be combined with the clinical practice, and serve the clinical. The teaching of clinical medicine is supposed to stimulate students' interest in learning and cultivate students' ability of independent analysis, problem-solving, communication and creation. WPBL can ensure that students get the ability of lifelong learning, and it can better meet the social demand for talents. China was faced with education and medical resources shortage in the past half century, and the teacher-centered traditional teaching mode could solve this problem effectively at that time. However, many deficiencies of the traditional teaching mode appear at the present stage of medical development, so clinical medicine teaching needs to keep pace with the times and the international community. WPBL can well solve the problems faced by the traditional education mode, but it is not widely popularized yet. Meanwhile, WPBL still needs some adjustments in some details, and the school should put the standardization of the teacher training of WPBL on the important agenda.

Surgery, as an important part of medicine, is characterized by prominent practical ability. However, the traditional teaching model can't meet the requirements of clinical practical operation, and WPBL teaching model just makes up for this shortcoming. WPBL teaching has changed the Force-feeding teaching which is prevalent in medical education. First students collect information through the network teaching platform in groups, and then group members look 
for ways actively to solve the problem, then discuss, ask questions and summarize mutually, eventually get solutions of the group, at last exchange the solutions with other groups on the Internet or in reality. WPBL teaching can break the limit of time and space; attract students with common interest in learning to establish a research group; improve the cooperation ability of students. Thus it is based on problem, student-centered, and it properly uses network resources to support group discussion teaching. Students are the main body in the activity of problem thinking, reasoning and analyzing (He, Oyang, Piao et al., 2013). WPBL teaching model stimulates students' enthusiasm to solve problems and explores the knowledge through the network resources and real case analysis. In the process of finding information and solving the problems, students can train their self-learning and information collecting ability, and cultivate their ability of independent thinking, and improve the ability of analysis and problem-solving (Zhang \& Lu, 2012). Obviously, compared with traditional teaching model, WPBL teaching model is more suitable for educating applied talents of surgery.

According to the survey results and analysis, we can draw the following conclusions: at present, teachers have a certain understanding about WPBL teaching model. Diversified understanding approach leads to inconsistent understanding, so the standardized teaching training for teachers is very necessary. At the same time, the students' high satisfaction degree for teaching and teachers approval indicate that WPBL teaching model can be recognized by the teachers and students to a great extent, which is conducive to the further popularization and application of the teaching mode.

\section{Epilogue}

WPBL teaching model, as a new teaching model, exerts undeniable advantages in the teaching process, but there must be certain shortcomings in application process. For example, WPBL teaching focuses on training ability and is easy to ignore the importance of basic theoretical knowledge. Therefore, we should notice that WPBL teaching actually emphasizes the application of basic knowledge in the application process. In today's surgery teaching, the disconnection between theory and practice is more serious. More theoretical knowledge and less training of clinical ability, more lecture time and less self-study time lead to such consequences as: medical knowledge learned cannot be applied to future clinical practice; the working adaptation period for graduates is too long; the operational ability of graduates is poor. WPBL can make up for the deficiency of today's surgery teaching, especially late education of surgery. After a previous theoretical knowledge learning, the teaching materials should be combined with clinic, mainly clinic, the theory should be combined with practice, mainly practice.

Meanwhile, due to the influence of the construction of the network platform, the basic literacy of the students and the cognitive ability of the teachers in the WPBL teaching method application process, and there is no systematic practical experience to draw lessons from, so the continuous exploration is needed in teaching practice. So not all the teaching content can be fully introduced into the 
WPBL teaching, but the progressive manner and the method of combining the traditional teaching method can be used to give students enough time to adapt to this new teaching method and improve students' theoretical and practical ability together, so as to better promote the reform of surgery teaching and improve teaching quality. All in all, in the future teaching process, we should continue to explore and sum up, make full use of the advantage of WPBL teaching method, and make it better to adapt to the cultivation of surgical talents.

\section{Foundation Item}

2016 Higher Education Reform Project in Guangxi (Project Number: 2016 JGA293).

\section{References}

Deng, C., Peng, L., \& Deng, X. Y. (2014). Application and Experience of WPBL Teaching Model in the Teaching Practice of Medical Laboratory. Laboratory Medicine and Clinic, $1,129-131$.

Han, X., Hu, Q. Y., Song, H. J. et al. (2012). Practice and Experience of WPBL Teaching Method in the Teaching of Human Anatomy. Journal of Qiqihar Medical College, 14, 1921-1922.

He, J. Q., Oyang, K. X., Piao, Z. G. et al. (2013). Application of PBL Teaching on Modern Internet in the Teaching of Oral and Maxillofacial Surgery. Course Education and Research, 21, 7-8.

Huang, Y. H., Ma, X. L., Cui, A. F. et al. (2014). Application of WPBL Teaching Method in the Biochemistry Teaching. China High Medical Education, 9, 122-123.

Li, J. J., Wang, Z. Q., \& Xiao, W. G. (2011). Practice of WPBL Teaching Method in Neurobiology Course. China High Medical Education, 7, 86+123.

Li, Y. C., Zhang, X., Huang, J. et al. (2016). Application of WPBL Teaching Model in Clinical Practice of Nephrology Department. Chinese Medical Record, 11, 77-80.

Liu, L. M. (2017). Enlightenment of American Humanistic Nursing Practice and Humanistic Spirit for China Humanistic Nursing Development. Nursing Research, 31, 118-119.

Long, X. S., Lu, Y. Y., Wei, G. F. et al. (2013). Exploration of WPBL Teaching Method in the "Microbiology Test" Teaching. China High Medical Education, 2, 118-119.

Neville, A. J. (2009). Problem Based Learning and Medical Education Forty Years on: A Review of Its Effects on Knowledge and Clinical Performance. Medical Principles \& Practice, 18, 1-9.

Wang, J. (2009). Analysis on the Reform of Clinical Surgery Teaching. Modern Medicine and Health, 5, 798-799.

Wei, G. F., Lu, Y. Y., Long, X. S. et al. (2010). Application of WPBL Teaching Method in the Clinical Laboratory Teaching. China High Medical Education, 12, 99-100.

Yang, S. F., Li, P. Q., \& Lin, S. N. (2014). Application of WPBL Teaching Model in Pathology Teaching. Health Vocational Education, 18, 40-41.

Zhang, J. L., \& Lu, Y. Y. (2012). Application of WPBL Teaching Model in the Teaching of Surgical Nursing. Journal of Nursing, 6, 61-63.

Zhao, J. J. (2013). Application and Exploration of WPBL Teaching Method in Preventive Medicine Teaching. Public Medical Forum Magazine, 16, 2147-2148. 
Submit or recommend next manuscript to SCIRP and we will provide best service for you:

Accepting pre-submission inquiries through Email, Facebook, LinkedIn, Twitter, etc. A wide selection of journals (inclusive of 9 subjects, more than 200 journals)

Providing 24-hour high-quality service

User-friendly online submission system

Fair and swift peer-review system

Efficient typesetting and proofreading procedure

Display of the result of downloads and visits, as well as the number of cited articles Maximum dissemination of your research work

Submit your manuscript at: http://papersubmission.scirp.org/

Or contact ce@scirp.org 